\title{
Family background and classroom belonging among adolescent students in Finland
}

\author{
Helena Hautala ${ }^{1}$ (D) $\cdot$ Hannu Lehti $^{1} \cdot$ Johanna Kallio $^{1}$
}

Accepted: 30 November 2021 /Published online: 12 January 2022

(c) The Author(s) 2021

\begin{abstract}
We study whether a family's economic situation and parental educational level are associated with classroom belonging among students in comprehensive secondary, upper secondary general and upper secondary vocational education in Finland. We also study whether there are educational-level differences in this possible association. We use survey data from the Finnish School Health Promotion study from 2017 $(\mathrm{N}=114,528)$. We conduct random effect linear probability models with schools as the second-level grouping variable. The results show that family's low economic situation predicts a higher probability of lack of sense of classroom belonging in Finland, despite the country having one of the world's most equal educational systems and comparably low economic inequality. Neither mother's nor father's educational level has any association. A family's low economic situation seems to predict the lack of a sense of belonging most strongly in comprehensive secondary education and most weakly in upper secondary vocational education. Our results slightly support the proposed significance of context-specific hierarchies in determining the association between economic resources and sense of belonging. A family having a poor economic situation is not reflected in the sense of classroom belonging as strongly in schools where students have a low average economic situation compared to those where students have a high average economic situation. We suggest measures, in addition to alleviating economic inequalities, to support the sense of school belonging, especially for low-income students.
\end{abstract}

Keywords Family background $\cdot$ Disadvantage $\cdot$ School belonging $\cdot$ Educational level

Helena Hautala

ahhaut@utu.fi

1 INVEST Research Flagship Center, University of Turku, 20014 Turku, Finland 


\section{Introduction}

Students' high sense of school and classroom belonging can be associated with various positive outcomes such as higher academic motivation and engagement, academic competence and achievement, self-efficacy, self-esteem and well-being in general (Ryan \& Patrick, 2001; Pittman \& Richmond, 2007; Niemiec \& Ryan, 2009). In contrast, students' lack of classroom belonging is consistently found to be associated with, for example, internalising and externalising behavioural problems, depressive symptoms, social anxiety, lower self-esteem, poorer academic performance, loneliness, alienation and eventually school dropout (Buhs \& Ladd, 2001; Chipuer, 2001; Pittman \& Richmond, 2007; Ream \& Rumberger, 2008; Foster et al., 2017).

Even though international research in particular has widely shown the association between school and classroom belonging and different positive outcomes, fewer studies have investigated the factors predicting belonging in the classroom. Existing findings have mostly concerned factors related to the school environment, such as teacher supportiveness, peer relationships and participation in extra-curricular activities (e.g. Wang \& Holcombe, 2010; Dotterer \& Lowe, 2011; Ryan \& Patrick, 2011). In contrast, the significance of family background, including family socioeconomic status (SES), has received less attention. Existing research concerning the significance of family background usually applies to higher education, focusing on working-class students in high-SES environments, such as universities (e.g. McGregor et al., 1991; Hertel, 2002; Pittman \& Richmond, 2007). SES is also usually treated as a unidimensional factor and thus does not produce information about the underlying mechanisms related to the possible association.

Sense of belonging is known to be a highly social phenomenon, and thus the context most likely affects which background factors influence the sense of classroom belonging and how they do so. Low family SES might not affect students' sense of belonging similarly at all levels of education. The association may also vary by student's age, as adolescence is a period of great transformation (Abbasi, 2016). To the best of our knowledge, the current study is the first to study the association between family background and classroom belonging in earlier educational stages in comprehensive and upper secondary education separately. We can also separate different dimensions of family SES, namely family's economic situation and parental educational level, in predicting classroom belonging at different educational levels.

The concept of sense of belonging largely overlaps with social capital, conceptually and theoretically, but also empirically: Ahn and Davis (2020) find that sense of belonging can be used as a simplified alternative way to measure social capital. Even if sense of belonging does not completely overlap with social capital, it is regarded as an important element for generating it (Wellman et al., 2001). Sense of school belonging can thus be regarded as students' social capital in the school environment.

This study investigates (1) Is the family SES, measured by the family's economic situation and parental educational level, associated with classroom 
belonging among 8th and 9th graders in comprehensive school (COM) and 1st and 2nd graders in upper secondary general (GEN) and upper secondary vocational (VOC) education? (2) Are there educational-level differences in the abovementioned association? As data, we use the School Health Promotion study, which provides survey data from Finland from $2017(\mathrm{~N}=114,528)$. Earlier research has indicated the importance of school-related factors, such as school climate and teacher supportiveness (Ma, 2003; Willms, 2003; Chiu et al., 2015). This can be taken into account by conducting a multilevel model using school as a second-level grouping variable. To be able to examine school-level differences, the interaction between family SES and school level is tested.

\section{Belonging as a basic need}

According to Maslow's (1943) theory of needs, a sense of belonging in a social group is a fundamental psychological need which must be satisfied before other needs, including self-actualisation, can be met. Both the belongingness hypothesis (Baumeister \& Leary, 1995) and the theory of self-determination (Deci \& Ryan, 1985) regard the need to belong as a basic human motivation. Sense of belonging is defined as feeling accepted and liked by the rest of the group, feeling connected to others and feeling like a member of a community (Baumeister \& Leary, 1995).

\subsection{Sense of belonging in the school and classroom}

During recent decades, more and more attention has been paid to the sense of belonging in educational contexts. The most commonly used definition of school belonging is by Goodenow (1993): "The extent to which students feel personally accepted, respected, included and supported in the school social environment". Korpershoek (2016) claims that students have a pervasive drive to form and maintain significant interpersonal relationships with their teachers and peers and a psychological need to create ties to the school as an institution. Belonging and connectedness with same-aged peers and adult figures outside the family, such as teachers, may hold particular importance as adolescents begin to transfer their dependencies from parents and families to extra-familial contexts (Allen, 2008; Österman, 2000; Demanet \& Van Houtte, 2012).

Having a sense of school belonging is perceived as a prerequisite for overall school functioning. Adolescents' sense of connectedness to school is found to be significantly associated with engagement, motivation and participation (Ryan \& Deci, 2009; Kiefer et al., 2015), academic attitudes and achievement (Ostrove \& Long, 2007; Pittman et al., 2007; Niemiec \& Ryan, 2009), better self-esteem and self-efficacy (Dotterer \& Wehrspann, 2016) and lower rates of emotional distress (Resnick et al., 1997). When students' needs to belong are not satisfied, diminished motivation, impaired development, alienation and poor performance are predicted (Deci et al., 1991). Baumester and Leary (1995) suggest that maladaptive school behaviours should be seen as "attempts to establish or maintain relationships with 
others or sheer frustration and purposelessness when one's need to belong goes unmet". A lower sense of belonging is shown to predict a risk of school dropout (Ream \& Rumberger, 2008; Merikukka et al., 2019).

\section{Family background and school belonging}

The scientific literature has regularly suggested that the social groups located at the bottom of the social hierarchy, such as low-SES individuals, suffer from a lack of recognition compared to individuals who are at the top of the social hierarchy (Fiske, 2010; Blader \& Chen, 2014). Hierarchies trigger shame and stress that negatively affect emotional and physical health and self-esteem (Twenge \& Campbell, 2002; Hertzman \& Boyce, 2010; Kraus \& Park, 2014). Individuals have been found to have a tendency to develop self-perceptions corresponding to, justifying and reproducing the hierarchy of the society they live in (Jost et al., 2004). The self-concept of low-SES individuals is described as an "undervalued self" by some authors (Kraus \& Park, 2014), and even the most competent low-SES students are found to face significant uncertainty regarding their recognition by others (Destin et al., 2017). However, to be able to feel belonging and connection to others, one has to feel safe both in one's social relations with peers and the larger community and with one's identity (Zhao et al., 2012).

\subsection{Family's economic situation and school belonging}

As SES is a multidimensional concept, we cannot understand the mechanisms underlying its effect without considering its different dimensions separately. Economic capital refers to access to economic resources. Modern theories emphasise the relative aspects of economic deprivation, especially in welfare states such as the Nordics. Relative poverty is a lack of ability to have an active social life and live a life on a par with others (Sen, 1983). The stigma caused by poverty may be a greater burden than the pure material consequences (Redmond, 2009). In children's lives, economic deprivation seems to actualise particularly in social relationships, especially with those children who possess better economic resources (Harju, 2008). Material resources are used in building a feeling of togetherness (Pugh, 2009; Buckingham, 2011), and having similar resources bond friends together (Hakovirta \& Rantalaiho, 2012), especially among youth (Croghan et al., 2006), both at school and in spare time (Korkiamäki \& Ellonen, 2011).

Wealth seems to bring social prestige and power, and lack of economic resources may cause shame, discrimination and exclusion (van der Hoek, 2005; Walker, 2014). Children of low-income families are found to suffer bullying and social exclusion more often than others (Ridge, 2002; Attree, 2006; Ridge, 2011), and some studies also find an association between family economic capital and school belonging (Chiu et al., 2015). Earlier research has pointed out that the resources that matter are those that are easily made visible (Hjalmarsson \& Mood, 2015). Even though economic resources are not the only factor affecting the sense of belonging and social 
integration, better economic resources offer children more options in regulating the image that other children have of them (Salmivalli, 2005). Economic resources seem to play a prominent role, especially during adolescence when children start to detach from their parents and form their own identities (Croghan et al., 2006; Murray, 2004; Deutsch \& Theodorou, 2009).

\subsection{Parental educational level and school belonging}

Parental educational level is usually regarded as indicating the cultural resources in the family. Home is an environment where the child learns to understand normative codes, dialect and cultural preferences about interacting and connecting with others in educational settings (Jaeger \& Holm, 2007). Mastering the normative codes helps the child to fare well socially, connect and feel belonging in school. According to the theory of cultural reproduction (Bourdieu \& Passeron, 1990), socialising to this norm system may be more difficult for working-class children with low parental education.

Although economic resources, especially those that are easily made visible, seem to be important for the sense of belonging, there is some evidence of the significance of parental educational level as well, although mainly from the higher education context. Social adjustment in universities is found to be more problematic for first-generation students (Hertel, 2002). Students with lower-educated parents are supposed to have fewer personal resources to meet the expectations of the higher education environment (Stephens et al., 2014). First-generation college students have a lower sense of belonging compared to their peers, even those whose parents have attended but not graduated from college (Pittman \& Richmond, 2007). Low parental education is also associated with the risk of being bullied at school (Nordhagen et al., 2005), but we found no earlier literature about the effect of parental education on the sense of belonging at lower degrees of education.

\section{Educational level and school belonging in Finland}

As needs are domain- and situation-specific and ongoing, the context plays a significant role in determining whether the individual needs for belonging are satisfied. If we assume that social hierarchies of power and prestige fuel a sense of belonging or, on the flip side, a sense of alienation and exclusion, it is also assumable that the association between different resources and sense of belonging varies according to contexts in different kinds of hierarchies. The same resources may not be similarly important at different educational levels. There is, nevertheless, no earlier research about the differences between educational levels in the association of family background and a sense of school belonging.

The 9 years of compulsory education in Finland are made up of 6 years of primary school (circa 7 to 12-year-olds) and 3 years of comprehensive secondary education (circa 13 to 15-year-olds) with no tracking. After comprehensive secondary education, children choose between upper secondary general and upper secondary 
vocational education, which both typically take 3 years to complete (circa 16 to 18-year-olds). Due to their joint comprehensive education, the students are a relatively heterogeneous group in terms of their family background before they move to upper secondary education. One may assume that heterogeneity reduces the significance of family background in predicting students' sense of belonging in comprehensive education. However, during their early adolescent years, children may be more vulnerable to peer pressure concerning consuming patterns, and at the same time, more dependent on their parents' economic resources.

Even though both tracks in upper secondary education are free of charge to attend, excluding study materials, SES-related selection also exists in Finland. In particular, choosing GEN education, which is the most common path to tertiary education and even more so to university, is highly predicted by parental educational level (SVT, 2019). Due to social selection, the student population in GEN and VOC education is more homogenous in terms of their family backgrounds compared to the COM student population. As the average SES is lower among VOC than GEN students, one could assume that low parental education and a poor economic situation would not be as stigmatising in VOC education and would thus not affect the sense of belonging as strongly. For the same reason, low SES is presumably a more significant risk factor for students in GEN than students in VOC education regarding school belonging.

The information produced in this study is valuable in trying to understand the mechanisms underlying the association between family SES and positive outcomes related to school belonging, such as commitment to education, one of the most crucial elements preventing social exclusion among adolescents (Bäckman \& Nilsson, 2011; Breen \& Karlson, 2013). Considering the fundamental importance of sense of belonging in the school environment, it is essential to understand its predictors. Chiu et al. (2015) regard belonging as critical in analysing connections between class and education.

\section{Data and methods}

\subsection{Data}

The data used, the School Health Promotion study from Finland from 2017, is conducted nationwide every other year for all 8th and 9th grade pupils in comprehensive school and 1st and 2nd grade students in GEN and VOC schools in Finland. In VOC schools, only students under 21 years old take part in the survey. The survey is conducted during the school day by teachers in classes, and students reply anonymously. In 2017, 63\% of 8th and 9th graders and 55\% of students in GEN institutions responded to the questionnaire. The share of the students in VOC could not be reliably counted. Altogether, 137,428 young people studying in upper comprehensive and upper secondary schools took part in the survey in 2017.

Participants with even one skipped question relevant to our research setting were deleted from the data. The data remain for 60,698 8th and 9th graders in upper comprehensive school, 32,043 students from GEN and 21,787 students from VOC and 
institutions. Approximately $19 \%$ of 8 th and 9th graders, $8 \%$ of students in GEN and $21 \%$ of VOC students were deleted from the data. The final sample size is 114,528 young people.

\subsection{Dependent variable}

The statement about feeling of belonging in one's class community was used as the dependent variable. Respondents were asked whether they agree or disagree with the statement "I regard myself as an important part of my classroom community". The response options were (1) Totally agree (2) Agree (3) Not agree nor disagree (4) Disagree (5) Totally disagree. The variable was transformed into two class variable by options one, two and three forming a reference category indicating a sense of belonging in the classroom and options four and five indicating a lack of sense of belonging. Out of all respondents, $90.1 \%$ regarded themselves as an important part of the classroom community, and $9.9 \%$ lacked that experience.

\subsection{Independent variables}

Family's economic situation and mother's and father's educational levels were used as independent variables reflecting students' family background. The variable measuring family's economic situation is based on the question "How would you describe the economic situation of your family" with response options (1) Very good (2) Good (3) Moderate (4) Bad (5) Very bad. The variable was transformed into three class variable by options one and two indicating a good economic situation acting as a reference category, option three indicating a moderate economic situation and options four and five indicating a poor economic situation in the student's family.

The original four category variables $(1=$ compulsory education, $2=$ secondary education, $3=$ additional professional studies for secondary education $4=$ tertiary education) measuring mother's and father's educational level were transformed into three category variables by combining the original classes two and three. Tertiary education stands for the reference category.

\subsection{Control variables}

Parental unemployment, respondents' gender, possible immigrant background and family type were controlled through the analysis. Parental unemployment is by no means a risk for a parent's sense of belonging in a society (Hiilamo, 2014). Social stigma may lead to a so-called culture of outsiders at home (Järvinen, 1999) and thus reflect on adolescents' sense of belonging in school. Gender was controlled, as the gap in school performance between boys and girls has been found to be the largest in Finland out of the OECD countries, and might well affect sense of belonging in school. An immigrant background is also found to be a risk factor for sense of belonging (Chiu et al., 2015; PISA, 2015). Most studies find that children living with two biological parents have higher levels of well-being, on average than children in stepfamilies and single-parent households, in part because two-biological-parent 
families are usually better equipped to provide key resources (Amato, 2010; Carr \& Springer, 2010).

\subsection{Data distribution}

The distribution (Appendix A) reveals that approximately $10 \%$ of the students lack a sense of belonging in the classroom. The poorer the family's economic situation and the lower the parental educational level, the more often students lack a sense of belonging. Fewer students lack a sense of belonging among respondents in VOC than at other educational levels. Children of unemployed parents, from one-parent families or with immigrant backgrounds lack a sense of belonging more often than others.

\subsection{Method}

Multilevel linear probability modelling was used as the primary method because the dataset includes information on both the individual and school level. Earlier research has indicated the high importance of environment-related factors for school belonging (Roorda et al., 2011; Allen et al., 2018). Due to regional segregation, differences in the association are assumed to occur within cities as well as between cities and the countryside. Thus, it is essential to take into account the social context of respondents.

With multilevel models, it is possible to take into account the similarity caused by the school environment. Multilevel analysis enables estimating Intra-Class Correlation (ICC), which here refers to the amount of resemblance between students at the same school in terms of their estimated sense of belonging. Comparison between the variance within schools and the variance between schools is thus enabled. More variance between than within schools would indicate higher context-dependency in evaluating sense of belonging. In this kind of situation, it is anticipated that the ICC will also be high. In contrast, less variance between than within school indicates the role of individual differences (such as differences in family background) in defining the sense of belonging in classroom, and the ICC is anticipated to be lower. The multilevel analysis produces more precise standard error terms than the individuallevel regression method, leading to more precise confidence intervals and significance test estimates.

\subsection{Analysis strategy}

The analysis strategy is as follows: First descriptive results are presented by conducting cross-tabulation on the associations of each independent variable with sense of belonging in the classroom. In the first multilevel analysis model, the association between the family's economic situation and the student's probability of lacking a sense of belonging in the classroom is investigated. In the second model, the association of mother's and father's educational levels with student's probability of lacking a sense of belonging in the classroom is examined. In the third model, both SES 
variables are introduced into the analysis simultaneously to control their effect on each other. In the last, fourth model, the respondent's school level is introduced into the analysis. Control variables are included in all models.

In the next phase, interaction tests are conducted to determine whether the factors indicating students' family background are differently associated with students' probability of lacking a sense of belonging at different educational levels. An interaction test is also conducted to explore the significance of context-specific hierarchies in educational level differences. Control variables are also included in the interaction tests. All the multilevel models are fitted as random intercept models that show coefficients for independent variables' variances at the school and individual levels. To estimate the extent to which the school differences explain the sense of belonging, intra-class correlations (ICC) are also calculated for the basic models.

\section{Results}

\subsection{Results of the multilevel analysis}

Model 1 (Table 1) shows that compared to students who evaluate their family's economic situation as good, those who evaluate it as moderate have a 4.3 percentage points higher probability of lacking a sense of belonging in the classroom. Those who evaluate their family's economic situation as poor have as much as a 14.7 percentage points higher probability of lacking a sense of belonging. This difference can be considered rather large.

Model 2 shows that the significance of both maternal and paternal education is small or negligible, although some estimates are statistically significant. Students whose mother has compulsory education have a 3.5 percentage points higher probability of lacking a sense of belonging in the classroom than students with tertiaryeducated mothers. This difference can be considered to be small. The estimate is also statistically significant and negative for children whose father has secondary education compared to children with a tertiary-educated father. However, the variable is a negligible predictor, as the difference is less than 1 percentage point.

Next, in model 3, both the family's economic situation and the mother's and father's educational levels are introduced to the model simultaneously. More information about the possible mechanisms underlying the associations is thus gained. The estimate of the family's economic situation remains unchanged, indicating that its association is not explained by parental educational level. The association of mother's compulsory educational level remains statistically significant, but the estimate diminishes by 1.0 percentage points. Father's secondary educational level does not change between models.

Finally, in the fourth model, the respondent's school level is introduced into the analysis. No change is observed in how the SES variables influence the probability of lacking a sense of belonging. Surprisingly, model 4 shows that compared to students in comprehensive education, students in VOC education have a 3.9 percentage points lower likelihood of lacking a sense of belonging. 
Table 1 Association of independent variables with sense of belonging in the classroom. All the random intercept models control for parental unemployment, gender, family type and immigrant background

\begin{tabular}{|c|c|c|c|c|}
\hline & Model 1 & Model 2 & Model 3 & Model 4 \\
\hline \multicolumn{5}{|l|}{ Economic situation (ref. good) } \\
\hline Moderate & $\begin{array}{l}0.043^{\text {*** }} \\
(0.002)\end{array}$ & & $\begin{array}{l}0.044 * * * \\
(0.002)\end{array}$ & $\begin{array}{l}0.044 * * * \\
(0.002)\end{array}$ \\
\hline Poor & $\begin{array}{l}0.147^{\text {**** }} \\
(0.004)\end{array}$ & & $\begin{array}{l}0.147 * * * \\
(0.004)\end{array}$ & $\begin{array}{l}0.148^{* * * *} \\
(0.004)\end{array}$ \\
\hline \multicolumn{5}{|c|}{ Parental educational level (ref. tertiary level) } \\
\hline Secondary education/Mother & & $\begin{array}{l}0.004 \\
(0.002)\end{array}$ & $\begin{array}{l}-0.001 \\
(0.002)\end{array}$ & $\begin{array}{l}0.000 \\
(0.002)\end{array}$ \\
\hline Compulsory education/Mother & & $\begin{array}{l}0.035^{* * *} \\
(0.004)\end{array}$ & $\begin{array}{l}0.025 * * * \\
(0.004)\end{array}$ & $\begin{array}{l}0.026 * * * \\
(0.004)\end{array}$ \\
\hline Secondary education/Father & & $\begin{array}{l}-0.008 * * * \\
(0.002)\end{array}$ & $\begin{array}{l}-0.014 * * * \\
(0.002)\end{array}$ & $\begin{array}{l}-0.012^{* * * *} \\
(0.002)\end{array}$ \\
\hline Compulsory education/Father & & $\begin{array}{l}0.005 \\
(0.004)\end{array}$ & $\begin{array}{l}-0.005 \\
(0.004)\end{array}$ & $\begin{array}{l}-0.003 \\
(0.004)\end{array}$ \\
\hline \multicolumn{5}{|c|}{ Respondent's school degree (ref. secondary comprehensive) } \\
\hline Upper secondary general & & & & $\begin{array}{l}0.001 \\
(0.003)\end{array}$ \\
\hline Upper secondary vocational & & & & $\begin{array}{l}-0.038^{* * * *} \\
(0.003)\end{array}$ \\
\hline Control variables & Yes & Yes & Yes & Yes \\
\hline Between school variance & 0.035 & 0.034 & 0.031 & 0.029 \\
\hline Within school variance & 0.293 & 0.295 & 0.293 & 0.293 \\
\hline ICC & 0.014 & 0.013 & 0.011 & 0.010 \\
\hline $\mathbf{N}$ & 114,528 & 114,528 & 114,528 & 114,528 \\
\hline
\end{tabular}

$* * * \mathrm{p}>0.001$ Empty model: between variance 0.040 , within variance 0.298 , ICC 0.018

When only the outcome variable is included in the model, on average, $2 \%$ of the total variation between students can be explained by variation between schools, i.e. the ICC is practically negligible. This indicates that differences in schools do not affect sense of belonging in the equal Finnish school system.

\subsection{Interactions between family SES and student's educational level}

Although parental educational level, excluding mother's compulsory education, did not appear to be a significant predictor of classroom belonging in our multilevel models, interactions between parental education and school level were tested to ensure that the findings apply at every level of education. Neither mother's nor father's educational level is significantly differently associated with classroom belonging at different levels of education (see Appendix B). 
Next, the focus is on the interaction between family's economic situation and educational level in predicting the sense of belonging in the classroom (Fig. 1). The interaction model reveals that a family's economic situation is statistically significantly differently associated with a lack of a sense of belonging at different educational levels. When moving from a family's good to average economic situation, the probability increases more among comprehensive and GEN students than among VOC students. Further, when moving from a family's average to poor economic situation, the difference is steeper and more notable. A poor economic situation seems to increase the probability of lacking a sense of belonging most for students in comprehensive education, i.e. 8th and 9th graders, and second-most for students in GEN institutions. The rise is most modest among students in VOC institutions.

As hierarchies are context-related, the probability of lacking a sense of belonging among respondents evaluating their family's economic situation good is next compared with those evaluating it as bad in environments with different average economic situations (Fig. 2). A variable indicating the average economic situation in each school was created, and schools were divided into five equally sized categories accordingly.

The original five category variables are used as the indicator of a family's economic situation. In comparison, only the extremities are considered: Students who evaluated their family's economic situation as good are compared with those evaluating it as bad in extreme contexts; i.e. in the fifth of schools where the average

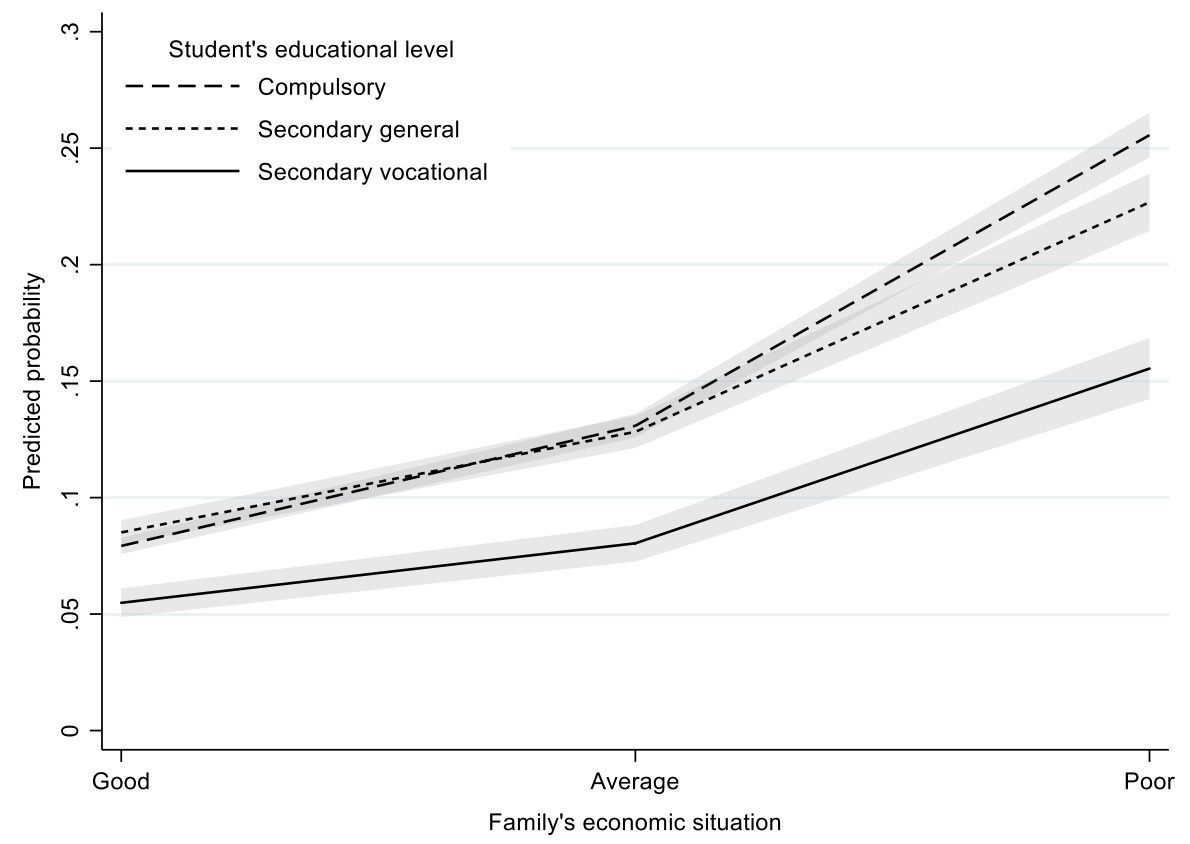

Fig. 1 Association between family's economic situation and probability of lacking a sense of belonging by respondent's school level. Random intercept LPM 


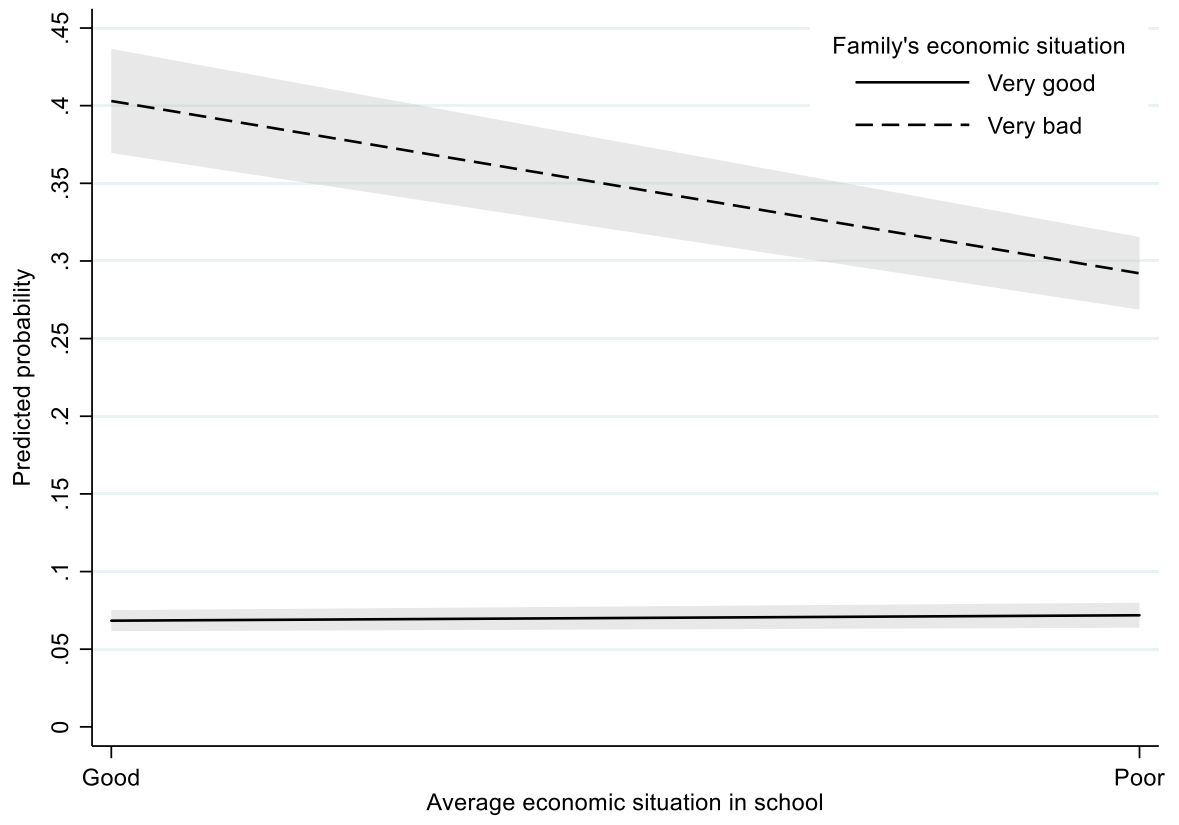

Fig. 2 School's average economic situation and probability of lacking a sense of belonging by family's economic situation

economic situation is evaluated as best and the fifth of schools where it is evaluated as worst. Control variables are included in the analysis.

The results show no context-related difference in the probability of lacking a sense of belonging among students who evaluate their family's economic situation as good. However, students whose family's economic situation is bad have a lower probability of lacking a sense of belonging in schools with a majority of students whose economic situation is bad than in schools with a majority of students with a good family economic situation.

\section{Conclusions}

This study examined whether a family's economic situation or parental educational level is associated with a student's probability of lacking a sense of belonging in the classroom. Moreover, it was investigated whether the association is different at three educational levels: COM, GEN and VOC education.

Multilevel analysis showed the low economic situation in the family to be the strongest and most consistent predictor of a lack of a sense of belonging in the classroom. The result supports the earlier findings on the importance of material possessions in adolescents' peer relationships and subjective well-being (e.g. Croghan et al., 2006; Main, 2014). Economic inequalities seem to be reflected straight onto young people's sense of belonging and involvement in the school 
context, even in Finland with its comparatively equal educational system and low income inequality in general.

The result is in line with the earlier understanding of economic resources and consumption as a means for adolescents to build their self-esteem, identity and selfconcept in relation to others (Murray, 2004; Deutsch \& Theodorou, 2009). The relationship between low economic resources and subjective well-being is well known, but the mechanisms remain unclear (Main, 2014). The lack of sense of belonging related to low economic resources may be one such mechanism. The perception that the significance of material resources extends their impact into educational contexts undermining such a crucial need as the need to belong is alarming, as education is regarded as the most important means of preventing intergenerational disadvantage.

Finding that maternal and paternal educational level is negligible in predicting sense of belonging can be considered surprising because parental education is found to be highly significant in predicting school dropout (e.g. Kallio et al., 2016). Even though sense of belonging also predicts school dropout, our results do not support the assumption that the association between parental educational level and school dropout is mediated by sense of school belonging. This was particularly surprising in relation to GEN education, as the average educational level of parents is higher in GEN (2019). In Sweden, parental educational level has been found to have lost its significance in predicting adolescents' subjective well-being, as the average educational level has reached a relatively high level (Plenty \& Mood, 2016). This may be the case in Finland as well, also reflected in a sense of belonging in school.

Among Finnish youth, family economic situation is more important than parental educational level in building a feeling of togetherness in the educational context. The results support Hjalmarson's and Mood's (2015) notion that the resources that matter are those that are easily made visible. In addition to alleviating economic inequalities, it is important to promote a sense of belonging in school contexts through both curricular and extra-curricular activities, especially among youth with low socioeconomic backgrounds and low family income. As schools rarely have information about students' families' economic situations, measures should be targeted at all students.

Another significant result from the analysis is that students in VOC institutions have a lower probability of lacking a sense of belonging than others, even after controlling for the family's economic situation and parental educational level. There are a variety of possible reasons for this unexpected result. It is appealing to interpret this difference as being due to differences in tendencies to answer questions, such as the so-called acquiescence bias, i.e. less-educated and less-informed respondents are more likely to acquiesce with statements than better-informed respondents (e.g. Krosnick, 1999). Nevertheless, if this interpretation was correct, students in COM education should remain somewhere between those in GEN and those in VOC education. This not being the case gives reason to expect that the change in either the tendency to reply to these kinds of statements or the change in conditions and experiences happens after moving from COM to VOC education.

One apparent difference that might explain the disparity is that students in VOC institutions study in groups based on their particular interests. It may be easier to build social cohesion with students studying in the same domain, despite their family 
backgrounds. From 1995 onwards, GEN institutions in Finland have been classless. Students are supposed to plan their own individual curricula, which may dilute social cohesion and the sense of belonging. It should also be taken into account that we have no reliable estimate of the share of VOC students that participated in the questionnaire. In addition, in the process of data editing, the highest loss emerged among students in VOC institutions. VOC students with the highest probability of lacking a sense of belonging may be missing from the data.

The modest ICC estimate was not expected. A multilevel model is not usually recommended with low ICC levels, but we consider it important here. It seems that in Finland, schools are not very different in their ability to produce a feeling of togetherness and cohesion. The result supports the understanding of the Finnish educational system as an equal one. In Finland, during comprehensive education, children mostly attend local public schools, while attending private school is very uncommon, which promotes educational equality. However, neighbourhood segregation with respect to equality of education has been discussed (Bernelius, 2013). The result also supports the premise of the importance of family background in predicting sense of belonging in the school context, rather than environment-related factors.

Interaction models between the family background and respondent's school level revealed that the student's educational level matters in estimating the association between family background and sense of belonging in the classroom. Students in COM education in the Finnish educational system are a highly heterogeneous population. Therefore, one could have assumed that family's economic situation would not be very significant, but our results claim the opposite. The significance of family's low economic situation for students in COM education may be explained by age: 14- and 15-year-olds are going through a phase where they, for the first time, start to detach from their childhood families and form their own identities, in the process of which economic resources and consumption seem to play a prominent role (Murray, 2004; Croghan et al., 2006; Deutsch \& Theodorou, 2009; Korkiamäki \& Ellonen, 2011). At the same time, they are still highly dependent on their parents and unable to affect their family's economic situation and their own economic resources (Salmivalli, 2005).

Nevertheless, the difference between students in GEN and VOC education cannot be explained by age. Social selection in upper secondary education is also apparent in our data, as the students in VOC education evaluated their families' economic situation as bad more often than students in GEN education. Based on knowledge about how social hierarchies build (Fiske, 2010; Blader \& Chen, 2014), the result may be interpreted as following from the worse average economic situation in families in VOC institutions. The result supports modern theories' understanding of poverty as relative. It is most important to be able to live life on a par with those near you (Sen, 1983). As economic deprivation seems to actualise particularly in social relationships (Harju, 2008), not in the form of pure material consequences (Redmond, 2009), a low economic situation may be less stigmatising and affect sense of belonging less in VOC than GEN institutions.

The results of the second interaction test give slight support for the interpretation of the importance of the context's average economic situation. If the interpretation 
applies - that the average economic situation in VOC schools is lower and reduces the probability of stigmatisation for students from low-income families - one could assume that selection between VOC and GEN would also evolve from where adolescents feel belonging and involvement, taking their socioeconomic background into account. This is nevertheless something the data used in this study cannot confirm.

Earlier literature has suggested that exceptionally advantaged children may also experience a lack of sense of belonging, but the results do not support this understanding. Of course, the classification is rough and cannot distinguish the most advantaged from others. Salmivalli (2005) suggests that even though economic resources do not determine young people's possibilities of a sense of belonging, well-subsidised youth have more possibilities to regulate the way they are seen. This phenomenon is also apparent in these results.

This study provides important new information regarding the factors predicting a sense of belonging in school during a crucial phase of the educational path, the transmission from compulsory to upper secondary education. To solve the problem of SES-based differences in educational success, choices and commitment, it is essential to pay attention not only to offering possibilities to attend but to young people's experiences in educational environments. Feeling "at home," safe and comfortable in school significantly affects school motivation. In addition to promoting equal income policies, it is particularly important to pay attention to promoting a sense of equality in children's and young people's daily life contexts by making school environments as neutral and free from economic inequalities and comparisons as possible and offering all children leisure-time activities equally.

There are also some shortcomings in this research. Data selection is a typical problem in research conducted using survey data. The data used here is nevertheless less selected than in most survey data, as it is collected nationwide during school days and all the students are supposed to participate in the questionnaire. Nevertheless, taking into account the higher risk for school dropout for adolescents with disadvantaged backgrounds, the data is more selected among students in upper secondary education and especially among students of VOC institutions. One may also question the reliability of the informants evaluating the family SES. It has been shown that children, particularly from low-SES families, do not know the educational level of their parents and tend to overestimate it (Engzell, 2015; Lehti \& Laaninen, 2021). Family's economic situation might be easier to evaluate, although it has also been found that parents may protect their children from information about economic hardship (Daly \& Kelly 2015). In future it would be fruitful to link data used here with Finnish register data sources to gain more reliable information about family background. In addition, this study does not show causal relationships between the studied variables, although many confounding variables were controlled in the models.

In the future, it would be fruitful to try to delve into the extent to which the assumed possibilities of gaining a sense of belonging affect educational choices. Second, it would be important to discover if the association between a family's low economic situation and sense of belonging exists as early as in primary school or even earlier. Third, it would also be desirable to reach young people with the highest risk of school dropout, who usually do not participate in survey questionnaires. 


\section{Appendices}

Appendix A. Data distribution regarding the sense of belonging in the classroom.

\begin{tabular}{lll}
\hline Background variable & Belonging & $\begin{array}{l}\text { Lack of } \\
\text { belong- } \\
\text { ing }\end{array}$ \\
\hline
\end{tabular}

\section{Economic situation}

Good economic situation

92,6

Moderate economic situation

87,6

Bad economic situation

76,3

23,7

Parent's level of education

Mother's tertiary level

90,4

9,6

Mother's secondary level

90,3

9,7

Mother's compulsory level

85,0

15,0

Father's tertiary level

90,0

10,0

Father's secondary level

90,5

9,5

Father's compulsory level

87,3

Respondent's school degree

Secondary comprehensive

89,6

10,4

Upper secondary general

88,8

11,2

Upper secondary vocational

93,3

6,7

\section{Gender}

Boys

93,4

6,6

Girls

87,0

Parental unemployment

No unemployment in the family

91,3

One or two parents unemployed

Family type

Two-parent family

90,7

9,0

One-parent family

88,0

Immigrant background

Both parents born in Finland

90,4

9,6

Immigrant background, born in Finland

87,6

Born outside Finland

80,6

19,4

Total

90,1

9,9

\section{Appendix}

Appendix B. The association between mother's and father's educational level and probability of lack of sense of belonging by respondent's school degree. Random intercept LPM. 


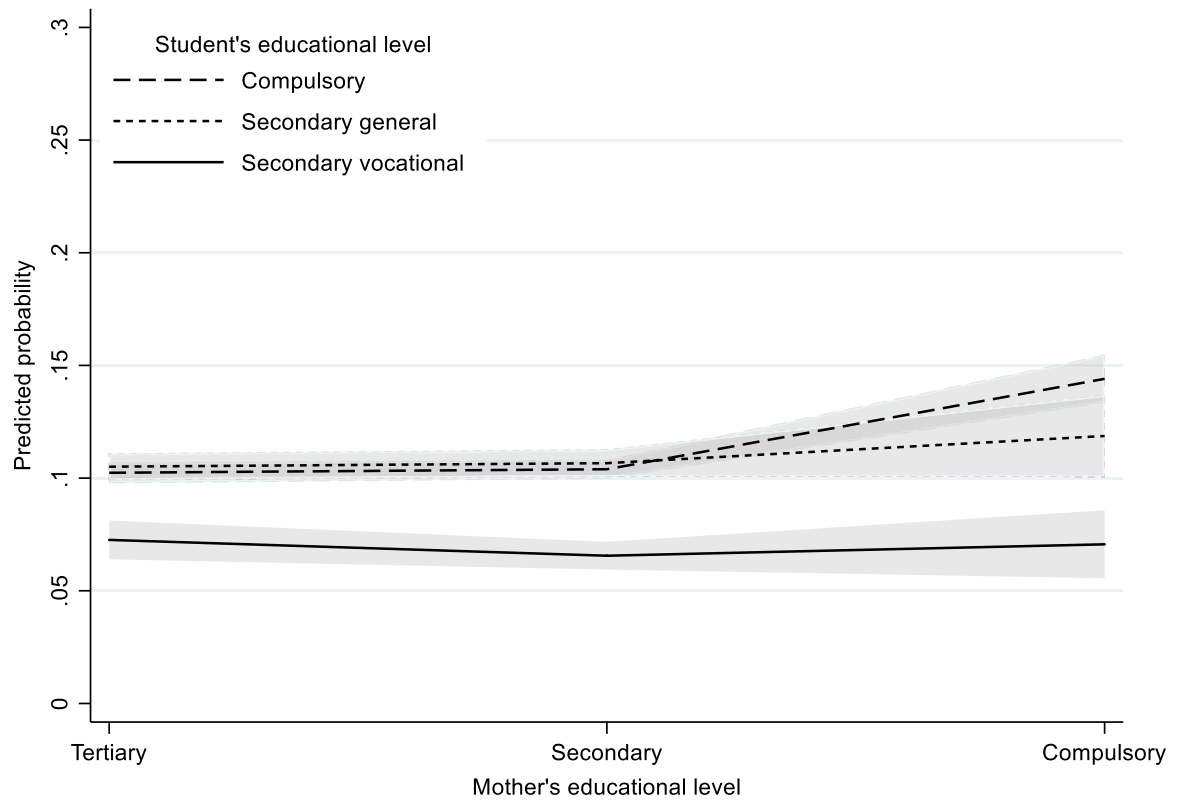

Fig. 3 School's average economic situation and probability of lacking a sense of belonging by family's economic situation

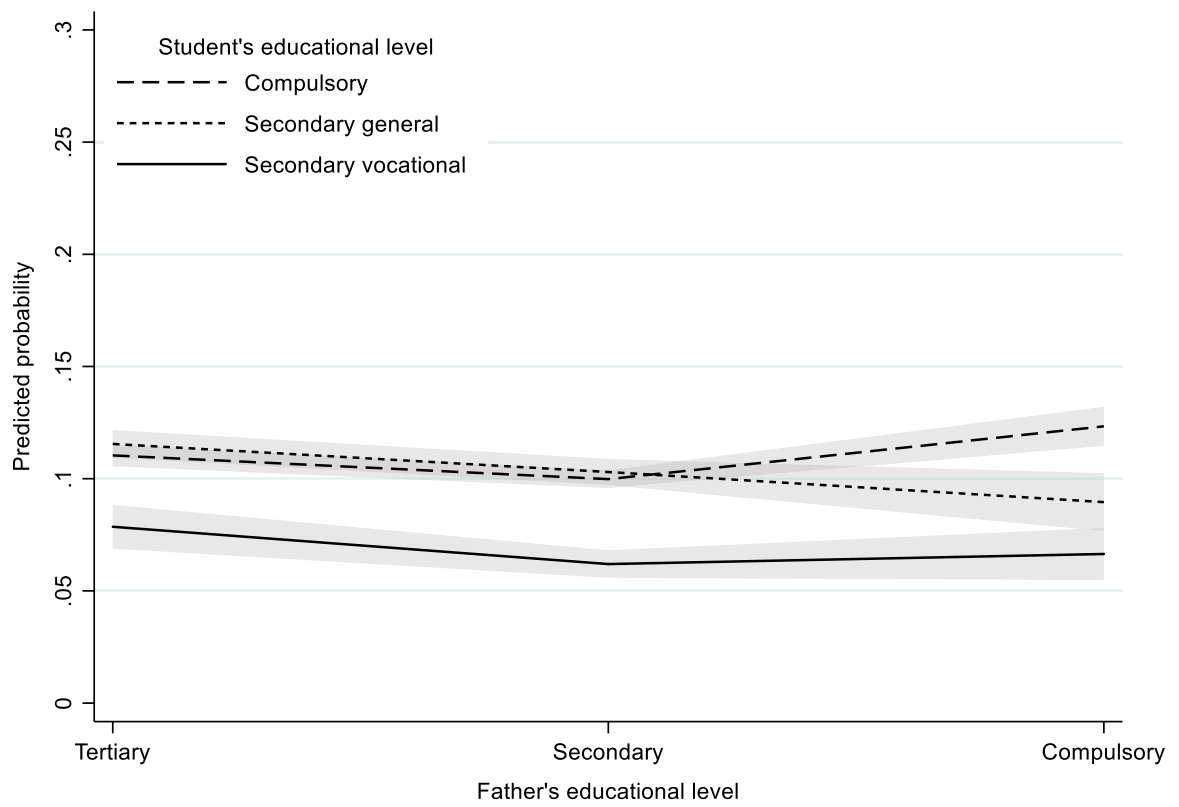

Fig. 4 School's average economic situation and probability of lacking a sense of belonging by family's economic situation 


\section{Funding}

Open Access funding provided by University of Turku (UTU) including Turku University Central Hospital. This work was supported by the Flagship Project of the Finnish Academy, Inequalities, Interventions and New Welfare State (INVEST) (grant number: 320162).

Conflict of interest The authors declare that there is no conflict of interest.

Open Access This article is licensed under a Creative Commons Attribution 4.0 International License, which permits use, sharing, adaptation, distribution and reproduction in any medium or format, as long as you give appropriate credit to the original author(s) and the source, provide a link to the Creative Commons licence, and indicate if changes were made. The images or other third party material in this article are included in the article's Creative Commons licence, unless indicated otherwise in a credit line to the material. If material is not included in the article's Creative Commons licence and your intended use is not permitted by statutory regulation or exceeds the permitted use, you will need to obtain permission directly from the copyright holder. To view a copy of this licence, visit http://creativecommons.org/licen ses/by/4.0/.

\section{References}

Abbassi, N. (2016). Adolescent identity formation and the school environment. In Fisher, K (Eds.), The translational design of schools: An evidence-based approach to aligning. Pedagogy and learning environments, 83-103. Sense Publishers.

Ahn, M., \& Davis, H. (2020). Sense of belonging as an indicator of social capital. International Journal of Sociology and Social Policy, 40(7), 627-642. https://doi.org/10.1108/IJSSP-12-2019-0258

Allen, J. (2008). The attachment system in adolescence. In Cassidy, J. \& Shaver P. R. (Eds.), Handbook of attachment: Theory, research, and clinical applications, 419-435. Guilford Press.

Allen, K., Kern, M., Vella-Brodrick, D., Hattie, J., \& Waters, L. (2018). What schools need to know about fostering school belonging: A meta-analysis. Educational Psychology Review, 30, 1-34. https://doi. org/10.1007/s10648-016-9389-8

Amato, P. (2010). Research on divorce: Continuing trends and new developments. Journal of Marriage and Family, 72(3), 650-666. https://doi.org/10.1111/j.1741-3737.2010.00723.x

Attree, P. (2006). The social costs of child poverty. A systematic review of the qualitative evidence. Children \& Society, 20(1), 54-66.

Bäckman, O., \& Nilsson, A. (2011). Pathways to social exclusion-a life-course study. European Sociological Review, 27(1), 107-123.

Baumeister, R., \& Leary, M. (1995). The need to belong: Desire for interpersonal attachments as a fundamental human motivation. Psychological Bulletin, 117(3), 497-529. https://doi.org/10.1037/00332909.117.3.497

Bernardi, F., \& Boado, H. (2014). Previous school results and social background: Compensation and imperfect information in educational transitions. European Sociological Review, 30(2), 207-217.

Bernelius, V. (2013) Eriytyvät kaupunkikoulut. Helsingin peruskoulujen oppilaspohjan erot, perheiden kouluvalinnat ja oppimistuloksiin liittyvät aluevaikutukset osana kaupungin eriytymiskehitystä. Helsingin kaupungin tietokeskus. Helsinki.

Blader, S. \& Chen, Y. (2014). What's in a name? Status, power, and other forms of social hierarchy. In J. T. Cheng, J. L. Tracy, \& C. Anderson (Eds.), The psychology of social status, 71-95. Springer.

Bourdieu, P. \& Passeron, J.-C. (1990). Theory, culture \& society. Reproduction in education, society and culture (2nd ed.) Sage Publications.

Breen, R., \& Karlson, B. (2013). Education and social mobility. New analytical approaches. European Sociological Review, 30(1), 107-118.

Buckingham, D. (2011). The material child. Growing up in consumer culture. Polity Press.

Buhs, E., \& Ladd, G. (2001). Peer rejection as antecedent of young children's school adjustment: An examination of mediating processes. Developmental Psychology, 37(4), 550-560. https://doi.org/10. 1037/0012-1649.37.4.550 
Carr, D., \& Springer, K. (2010). Advances in families and health research in the 21st century. Journal of Marriage and Family, 72(3), 743-761. https://doi.org/10.1111/j.1741-3737.2010.00728.x

Chipuer, H. (2001). Dyadic attachments and community connectedness: Links with youths' loneliness experiences. Journal of Community Psychology, 29(4), 429-446.

Chiu, M., Chow, B., McBride, C., \& Mol, S. (2015). Students' sense of belonging at school in 41 countries: Cross-cultural variability. Journal of Cross-Cultural Psychology, 47(2), 175-196. https://doi. org/10.1177/0022022115617031

Croghan, R., Griffine, C., Hunter, J., \& Phoenix, A. (2006). Style failure. Consumption, identity and social exclusion. Journal of Youth Studies, 9(4), 463-478.

Daly, M. \& Kelly, G. (2015). Families and poverty: Everyday life on a low income. Published to Policy Press scholarship online. DOI: https://doi.org/10.1332/policypress/9781447318828.001.0001

Deci, E. \& Ryan, R. (1985). Intrinsic motivation and self-determination in human behavior. Plenum.

Deci, E., Vallerland, R., Pelletier, L., \& Ryan, R. (1991). Motivation and education: The self-determination perspective. Educational Psychologist, 26, 325-346. https://doi.org/10.1207/s15326985e p2603\&4_6

Demanet, J., \& Van Houtte, M. (2012). School belonging and school misconduct: The differing role of teacher and peer attachment. Journal of Youth and Adolescence, 41(4), 499-514.

Destin, M., Rheinschmidt-Same, M., \& Richeson, J. (2017). Status-based identity: A conceptual approach integrating the social psychological study of socioeconomic status and identity. Perspectives on Psychological Science, 12(2), 270-289. https://doi.org/10.1177/1745691616664424

Deutsch, N., \& Theodorou, E. (2009). Aspiring, consuming, becoming: Youth identity in a culture of consumption. Youth \& Society, 42(2), 229-254.

Dotterer, A., \& Lowe, K. (2011). Classroom context, school engagement and academic achievement in early adolescence. Journal of Youth and Adolescence, 40(20), 1649-1660. https://doi.org/10. 1007/s10964-011-9647-5

Dotterer, A., \& Wehrspann, E. (2016). Parent involvement and academic outcomes among urban adolescents: Examining the role of school engagement. Educational Psychology, 36(4), 812-830. https://doi.org/10.1080/01443410.2015.1099617

Engzell, P., \& Jonsson, J. (2015). Estimating social and ethnic inequality in school surveys: Biases from child misreporting and parent nonresponse. European Sociological Review, 31(3), 312-325.

Fiske, S. (2010). Interpersonal stratification. Status, power and subordination. In Fiske, S., Gilbert, D. \& Lindzey, G. (Eds.), Handbook of social psychology, 941-982. Wiley.

Foster, C., Horwitz, A., Thomas, A., Opperman, K., Gipson, P., Burnside, A., Stone, D., \& King, A. (2017). Connectedness to family, school, peers, and community in socially vulnerable adolescents. Children and Youth Services Review, 81, 321-333. https://doi.org/10.1016/j.childyouth. 2017.08.011

Goodenow, C. (1993). The psychological sense of school membership among adolescents: Scale development and educational correlates. Psychology in the Schools, 30(1), 79-90. https://doi.org/ 10.1002/1520-6807(199301)30:1<79::AID-PITS2310300113>3.0.CO;2-X

Hakovirta, M. \& Rantalaiho M. (2012). Taloudellinen eriarvoisuus lasten arjessa. Sosiaali- ja terveysturvan tutkimuksia 124 . Kela.

Harju, A. (2008). Barns vardag med knapp ekonomi. En studie om barns erfarenheter och strategier. Växjö: Växjö University, Acta Wexionensia (vårdvetenskap och socialt arbete) 137.

Hertel, J. (2002). College student generational status: Similarities, differences, and factors in college adjustment. Psychological Record, 52(1), 3-18.

Hertzman, C., \& Boyce, T. (2010). How experience gets under the skin to create gradients in developmental health. Annual Review of Public Health, 31, 329-334.

Hiilamo, H. (2014). Voiko osallistava sosiaaliturva lisätä osallisuutta? Yhteiskuntapolitiikka, 1.

Hjalmarsson, S., \& Mood, C. (2015). Do poorer youth have fewer friends? The role of household and child economic resources in adolescent school-class friendships. Children and Youth Services Review, 58, 201-211.

van der Hoek, T. (2005). Through children's eyes. An initial study of children's personal experiences and coping strategies growing up poor in an affluent Netherlands. UNICEF, Innocenti.

Jaeger, M., \& Holm, A. (2007). Does parents' economic, cultural and social capital explain the social class effect on educational attainment in the Scandinavian mobility regime? Social Science Research, 36(2), 719-744. 
Järvinen, T. (1999). Koulutuksen ja työelämän ulkopuolella. In Kuorelahti, M \& Viitanen, R (Eds.), Holtittomasta hortoilusta hallittuun harhailuun. Nuorten syrjäytymisen riskit ja selviytymiskeinot, 189-196. Mannerheimin Lastensuojeluliitto, Nuorisoasiain neuvottelukunta.

Jost, J., Banaji, M., \& Nosek, B. (2004). A decade of system justification theory: Accumulated evidence of conscious and unconscious bolstering of the status quo. Political Psychology, 25(6, 881), -919. https://doi.org/10.1111/j.1467-9221.2004.00402.x

Kallio, J., Kauppinen, T., \& Erola, J. (2016). Cumulative socioeconomic disadvantage and secondary education in Finland. European Sociological Review, 32(5), 649-661.

Kiefer, S., Alley, K., \& Ellerbrock, C. (2015). Teacher and peer support for young adolescents' motivation, engagement and school belonging. RMLE Online, 38(8), 1-18. https://doi.org/10.1080/ 19404476.2015.11641184

Korkiamäki, R., \& Ellonen, N. (2011). Ikätoverisuhteet sosiaalisina resursseina yläkouluiässä. Nuorisotutkimus, 28(3), 18-35.

Korpershoek, H. (2016). Relationships among motivation, commitment, cognitive capacities and academic achievement in secondary education. Frontline Learning Research, 4(3), 28-43. https://doi. org/10.14786/flr.v4i3.182

Kraus, M., \& Park, J. (2014). The undervalued self: Social class and self-evaluation. Frontiers in Psychology, 5(1-9), 1404. https://doi.org/10.3389/fpsyg.2014.01404

Krosnick, J. (1999). Survey research. Annual Review of Psychology, 50(1), 537-567. https://doi.org/10. 1146/annurev.psych.50.1.537

Lehti, H., \& Laaninen, M. (2020). Perhetaustan yhteys oppimistuloksiin Suomessa PISA-ja rekisteriaineistojen valossa. SocArXiv. September 23. DOI:10.31235/osf.io/zrhqc.

Ma, X. (2003). Sense of belonging to school: Can schools make a difference? The Journal of Educational Research, 96(6), 340-349. https://doi.org/10.1080/00220670309596617

Maslow, A. H. (1943). A theory of human motivation. Psychological Review, 50(4), 370-396. https://doi. org/10.1037/h0054346

McGregor, L., Mayleben, M., Buzzanga, V., Davis, S., \& Becker, A. (1991). Selected personality characteristics of first-generation college students. College Student Journal, 25(2), 231-234.

Merikukka, M., Ristikari, T., \& Kiilakoski, T. (2019). Suojaako yläkouluikäisten nuorten osallisuuden kokemus koulussa lyhyeltä koulutuspolulta? Yhteiskuntapolitiikka, 84(4), 403-415.

Murray M. (2004). Freaks, geeks, and cool kids. American teenagers, schools, and the culture of consumption (1st Ed.). Imprint Routledge.

Niemiec, C., \& Ryan, R. (2009). Autonomy, competence and relatedness in the classroom: Applying self-determination theory to classroom practice. Theory and Research in Education, 7(2), 133-144. https://doi.org/10.1177/1477878509104318

Nordhagen, R., Nielsen, A., Stigum, H., \& Kohler, L. (2005). Parental reported bullying among Nordic children: A population-based study. Child Care Health and Development, 31(6), 693-701. https:// doi.org/10.1111/j.1365-2214.2005.00559.x

Österman, K. (2000). Students' need for belonging in the school community. Review of Educational Research, 70(3), 323-367. https://doi.org/10.2307/1170786

Ostrove, J., \& Long, S. (2007). Social class and belonging: Implications for college adjustment. The Review of Higher Education, 30(4), 363-389. https://doi.org/10.1353/rhe.2007.0028

Pittman, L., \& Richmond, A. (2007). Academic and psychological functioning in late adolescence: The importance of school belonging. The Journal of Experimental Education, 75(4), 270-290. https:// doi.org/10.3200/JEXE.75.4.270-292

Plenty, S., \& Mood, C. (2016). Money, peers and parents: Social and economic aspects of inequality in youth wellbeing. Journal of Youth and Adolescence, 45(7), 1294-1308.

Pugh, A. (2009). Longing and belonging. Parents, children and consumer culture. University of California Press.

Ream, R., \& Rumberger, R. (2008). Student engagement, peer social capital, and school dropout among Mexican American and non-Latino white students. Sociology of Education, 81(2), 109-139. https:// doi.org/10.1177/003804070808100201

Redmond, G. (2009). Review article. Children as actors. How does the child perspectives literature treat agency in the context of poverty? Social Policy \& Society, 8(4), 541-550.

Resnick, M., Bearman, P., Blum, R., Bauman, K., Harris, K., Jones, J., Tabor, J., Beuhring, T., Sieving, R., Shew, M., Ireland, M., Bearinger, L., \& Udry, J. (1997). Protecting adolescents from harm: Findings from the national longitudinal study on adolescent health, The Journal of the American Medical Association., 278(10), 823-832. https://doi.org/10.1001/jama.278.10.823 
Ridge T. (2002). Childhood poverty and social exclusion: From a child's perspective. Policy Press.

Ridge, T. (2011). The everyday costs of poverty in childhood. A review of qualitative research exploring the lives and experiences of low-income children in the UK. Children \& Society, 25(1), 73-84.

Roorda, D., Koomen, H., Spilt, J., \& Oort, F. (2011). The influence of affective teacher-student relationships on students' school engagement and achievement: A meta-analytic approach. Review of Educational Research, 81(4), 493-529. https://doi.org/10.3102/0034654311421793

Ryan, R. \& Deci, E. (2009). Promoting self-determined school engagement: Motivation, learning, and well-being. In Wentzel, K. \& Miele, D. (Eds.), Handbook on motivation at school, 171-196. Routledge.

Ryan, A., \& Patrick, H. (2001). The classroom social environment and changes in adolescents' motivation and engagement during middle school. American Educational Research Journal, 38(2), 437460. https://doi.org/10.3102/00028312038002437

Salmivalli, C. (2005). Kaverien kanssa. Vertaissuhteet ja sosiaalinen kehitys. PS-Kustannus.

Sen, A. (1983). Poor, relatively speaking. Oxford Economic Papers, New Series, 35(2), 153-169.

Stephens, N., Hamedani, M., \& Destin, M. (2014). Closing the social-class achievement gap: A difference-education intervention improves first generation students' academic performance and all students' college transition. Psychological Science, 25(4), 943-953. https://doi.org/10.1177/09567 97613518349

SVT (2018). Koulutuksen keskeyttäminen. ISSN=1798-9280. 2018. Tilastokeskus [17.6.2021]. http:// www.stat.fi/til/kkesk/2018/kkesk_2018_2020-03-12_tie_001_fi.html

SVT (2019). Opintojen kulku. ISSN=1799-1005. 2019. Tilastokeskus [17.6.2021]. http://www.stat.fi/til/ opku/2019/opku_2019_2019-03-14_tie_001_fi.html

Terenzini, P. (1996). First-generation college students: Characteristics, experiences, and cognitive development. Research in Higher Education, 37(1), 1-22.

Twenge, J., \& Campbell, W. (2002). Self-esteem and socioeconomic status: A meta-analytic review. Personality \& Social Psychology Review, 6(1), 59-71. https://doi.org/10.1207/s15327957pspr0601

Wang, M., \& Holcombe, R. (2010). Adolescents' perceptions of school environment, engagement, and academic achievement in middle school. American Educational Research Journal, 47(3), 633-662. https://doi.org/10.3102/0002831209361209

Wellman, B., Haase, A., Witte, J., \& Hampton, K. (2001). Does the Internet increase, decrease, or supplement social capital? Social networks, participation, and community commitment. American Behavioral Scientist, 45(3), 436-455.

Willms, J. (2003). Student engagement at school: A sense of belonging and participation: Results from PISA 2000. OECD Publishing. https://doi.org/10.1787/9789264018938-en.

Zhao, L., Lu, Y., Wang, B., Chau, P., \& Zhang, L. (2012). Cultivating the sense of belonging and motivating user participation in virtual communities: A social capital perspective. International Journal of Information Management, 32(6), 574-588. https://doi.org/10.1016/j.ijinfomgt.2012.02.006

Publisher's Note Springer Nature remains neutral with regard to jurisdictional claims in published maps and institutional affiliations. 